\title{
Thymic Clear Cell Carcinoma
}

National Cancer Institute

\section{Source}

National Cancer Institute. Thymic Clear Cell Carcinoma. NCI Thesaurus. Code C6462.

A rare, usually aggressive, primary thymic carcinoma, characterized by the presence of carcinoma cells with clear cytoplasm. 